\title{
The life history of Megaleptoperla diminuta (Plecoptera : Gripopterygidae) in Waikoropupu Springs, New Zealand
}

\author{
F.B. Michaelis ${ }^{\mathrm{I}}$
}

The endemic Megaleptoperla diminuta (Plecoptera : Gripopterygidae) was numerous on in troduced watercress, Nasturtium microphyllum in Waikoropupu Springs, New Zealand. Adult females laid eyed ova. There appear to be about 15 nymphal instars and a non-seasonal, one year life cycle. Ovoviviparity and viviparity in Australian and New Zealand Plecoptera and Trichoptera may be associated with seasonal aquatic vegetation and fluctuating water levels.

Le cycle de Megaleptoperla diminuta (Plecoptera : Gripopterygidae) dans les sources Waikoropupu, Nouvelle Zélande.

Le Plécoptère endémique Megaleptoperla diminuta est abondant sur le cresson (Nasturtitum microphyllum, espèce introduite) dans les sources Waikoropupu (Nouvelle Zélande). Les femelles pondent des ceufs contenant des larvules oculées. Il semble y avoir environ 15 stades larvaires et un cycle non-saisonnier d'une durée d'un an. L'ovoviviparité et la vivipa. rité chez les Plécoptères et Trichoptères d'Australie et de Nourelle Zélande sont peutêtre associées à une végétation aquatique saisonnière et aux fluctuatiens du niveau de l'eau.

\section{1. - Introduction}

In recent years, interest in the biology of the Southern Hemisphere stoneflies (Antarctoperlaria) has grown.

The eggs of the eustheniids Stenoperla maclellani (= S. prasina of Helson) in New Zealand and Eusthenia spectabilis in Australia were described by Helson (1935) and Rait (1937) respectively. It was not until the 1970s that the eggs of 33 species of Australian stoneflies were described and figured (Hynes 1974) and the lengths of development of some of them recorded (Hynes \& Hynes 1975). The first instar nymphs of 25 species were described by Sephton \& Hynes (1982 b).

The only reliable determinations of instar number have been made for Paragripopteryx anga (Gripopterygidae) in South America by Froehlich (1969) ;

1. Cawthron Institute, Nelson and Zoology Department, University of Canterbury, Christchurch, New Zealand. Present address : Nature Conservation Evaluation Branch, Australian National Parks \& Wildlife Service, G.P.O. Box 636, Canberra. A.C.T. 2601, Australia. for S. prasina (Eustheniidae) in New Zealand by Winterbourn (1974) and for ten species in Australia (including seven gripopterygids) by Sephton \& Hynes (1982 a).

In New Zealand, the life histories of Zelandoperia decorata $(=Z$. maculata of Winterbourn 1966), Acroperla trivacuata (= Aucklandobius trivacuatus) (Gripopterygidae) and S. prasina were described by Winterbourn $(1966,1974)$ and some life history information on four species (Austroperlidae, Gripopterygidae and Notonemouridae) was given by Winterbourn (1978). The life histories of six species remain unpublished by B. Cowie (pers. comm.). In Australia, the life histories of 27 species were worked out in detail by Hynes \& Hynes (1975).

As part of an ecological study of Waikoropupu Springs, Takaka, North West Nelson, New Zealand (Michaelis 1976 b, 1977), some information on the life history of the endemic Megaleptoperla diminuta Kimmins, 1938 (Plecoptera: Gripopterygidae), the only stonefly present, was obtained. The nymph of this species awaits description by I.D. McLellan but is included in his key (McLellan 1977). Representatives of all stages on which this paper was originally based were lodged with the New Zealand Arthropod 

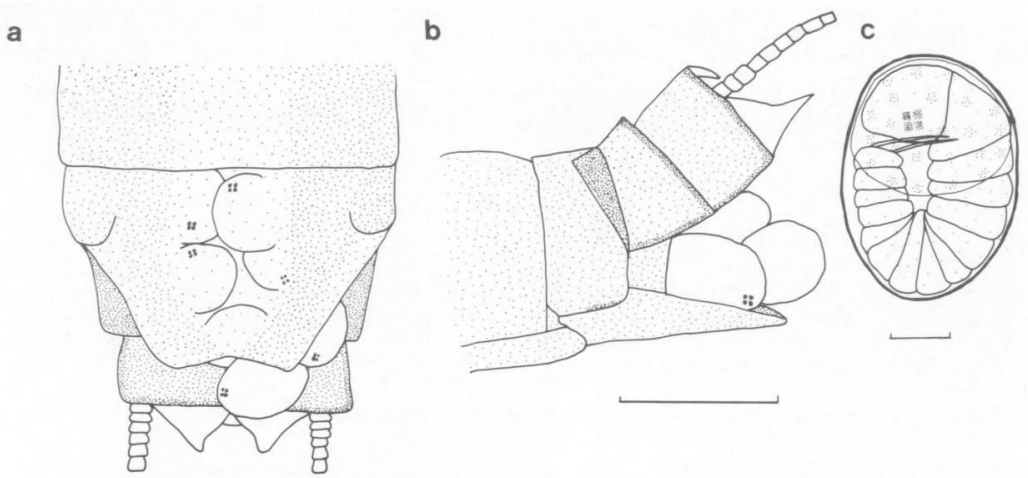

Fig. 1. Megaleptoperla diminuta : a, ventral view of female abdomen to show laying of eyed ova ; b, id., lateral view, scale line $1 \mathrm{~mm}$; c, newly laid egg, scale line $100 \mu \mathrm{m}$.

Collection in 1974 but they were subsequently lost (1979). Two adult females from the original collection were kindly made available by I.D. McLellan.

\section{2. - Study area and methods}

Waikoropupu Springs are the largest cold springs in New Zealand, with a maximum depth of $6.9 \mathrm{~m}$ and a mean water discharge of $9.6 \mathrm{~m}^{3} \cdot \mathrm{s}^{-1}$. The temperature of the Springs water is constant at $11.7^{\circ} \mathrm{C}$ and water velocities are generally moderate to very strong (0.25-1 m.s.1) (Michaelis $1976 \mathrm{~b}$ ).

Methods for collection of specimens of Megaleptoperla diminuta from the introduced watercress, Nasturtium microphyllum (Boenn.) Rchb. and their preservation have been outlined in previous papers (Michaelis $1976 \mathrm{a}, 1977$ ).

Head capsule widths of nymphs were measured to $0.003 \mathrm{~mm}$ for each individual using a calibrated ocular micrometer under a dissection microscope at magnification of $25 x$. Head capsule measurements of first instar nymphs were obtained from individuals dissected from eggs. A size-frequency histogram of head capsule widths was not sufficient to separate the instars and the Janetschek method, critically reviewed by Fink (1980) and outlined in Sephton \& Hynes (1982 a), was adopted to clarify the situation. In addition, wing pad length was measured to separate antepenultimate $(F-2)$, penultimate $(F-1)$ and final $(F)$ instars and where possible, the sexes were graphed separately in the F $-2, F-1$ and F instars. A semilog plot of head capsule width against instar number was made to determine the growth pattern of the species and its conformity with Brooks' (= Dyar's) Rule (Crosby 1973).

Individuals were assigned an instar number. Data from all sites (Michaelis 1977) were combined $(n=233)$ to give nymphal size distribution of each 4-weekly sample. Eggs were not collected in the field but were dissected from the ovary of an adult fernale and later obtained from an additional egg-laying female.

\section{3. - Results}

The post-abdomen of an egg-laying female is represented in Fig. 1 a, b. Note that the extended sternite 8 has a curved rim to hold the eggs when segments 9 and 10 are elevated. Eggs were white, ovoid and $0.42 \mathrm{~mm}$ long and developing nymphs had a headwidth $0.25 \mathrm{~mm}$ (Fig. I c).

Final instar nymphs had a head capsule width of $1.73 \mathrm{~mm}(\sigma)$ and $1.87 \mathrm{~mm}(\%)$ (total $\mathrm{n}=24$ ). Three difficulties encountered in interpreting head width size - frequency data were the considerable overlap 
apparent between $\mathbf{F}-\mathbf{2}, \mathbf{F}-1$ and $\mathbf{F}$ instars (although these were separated by wing pad length measurements), sexual dimorphism which probably occurred in later instars and the absence of the smaller instars from field collections.

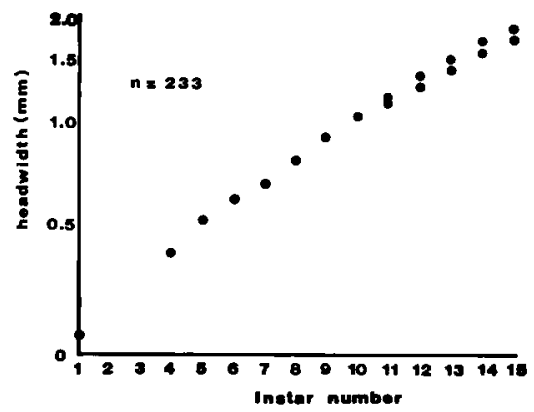

Fig. 2. The number of instars for Megaleptoperla diminuta, Waikoropupu Springs. Semi-logarithmic plot of head capsule width against instar number. Pairs of circles for instars 11.15 represent possible sexual dimorphism.

It was concluded that $M$. diminuta has 15 nymphal instars in Waikoropupu Springs (Fig. 2). Instar numbers 1,2 and 3 were not collected in the field. Growth conformed with Brooks' Rule in the first 11 instars but the growth rate was lower in the last four instars when probable sexual dimorphism also became apparent (Fig. 2).

Fig. 3 shows the instar distribution for Waikoropupu Springs. The smallest nymphs (instar 4) were taken in November 1970; March, August and November 1971. Final instar nymphs were collected in November 1970, June 1971 and September/October 1971 but numbers were small. Final instar exuviae were found over three full months (August to November 1971). Adults were netted on one occasion only, at the edge of the Springs just before noon on a warm calm day (1 May 1971 = Autumn). Adults have been collected in January, July, October and November elsewhere in the South Island (I.D. McLellan pers. comm.). Data on nymphal size distribution for this species are difficult to interpret, but the most likely explanation is of a one-year life cycle with two cohorts growing at an equal rate. The emergence periods are extended with one cohort present as adults in spring (October) and the other in autumn (May). Adults need to be long lived to permit development of 1 st instar nymphs in the eggs which could then be laid in November and June respectively. Nymphal growth appears to occupy nearly a year; in fact 15 instars during 11 months averages three weeks per instar, which is in reasonable agreement with laboratory rearings at $12^{\circ} \mathrm{C}$ (Michaelis unpublished data).

\section{4. - Discussion}

The 15 nymphal instars calculated for $M$. diminuta in Waikoropupu Springs is the same as the number postulated for S. prasina (Winterbourn 1974) and is slightly higher than the 10-14 for seven species of Australian Gripopterygidae (Sephton \& Hynes 1982 a).

Mature eggs have been found in final instar nymphs of both Megaleptoperla diminuta and $M$. grandis (McLellan 1977). The finding of eyed ova in adult females of $M$. diminuta in the present study suggested this species was ovoviviparous and this is the third report of ovoviviparity in the family Gripopterygidae, following Zwick (1973) for Antarctoperla michaelseni from South America and Zwick (1980, 1981) for Leptoperla sp. from Tasmania.

Ovoviviparity and viviparity as life history strategies provide a stable internal environment for young in unfavourable habitats and are known in a number of Sou thern Hemisphere Plecoptera and Trichoptera (Table I). In Australia the habitat of Austrocerca tasmanica may have a changing water level (Hynes 1974) as with the temporary waterways populated by Triplectides spp. (Morse \& Neboiss 1982 ) and by some $T$. cephalotes in New Zealand (Cowley 1978). By contrast, in the Capniidae, ovoviviparity may be an adaptation by early emerging species to low water temperatures (Hynes 1976).

Ovoviviparity is found even in relatively stable physical environments, for example, vegetation in spring-fed running waters inhabited by $M$. diminuta (McLellan 1975) and waterweeds in lakes inhabited by the caddis Triplectides cephalotes (Pendergrast $\&$ Cowley 1966). Ovoviviparity may have evolved as 


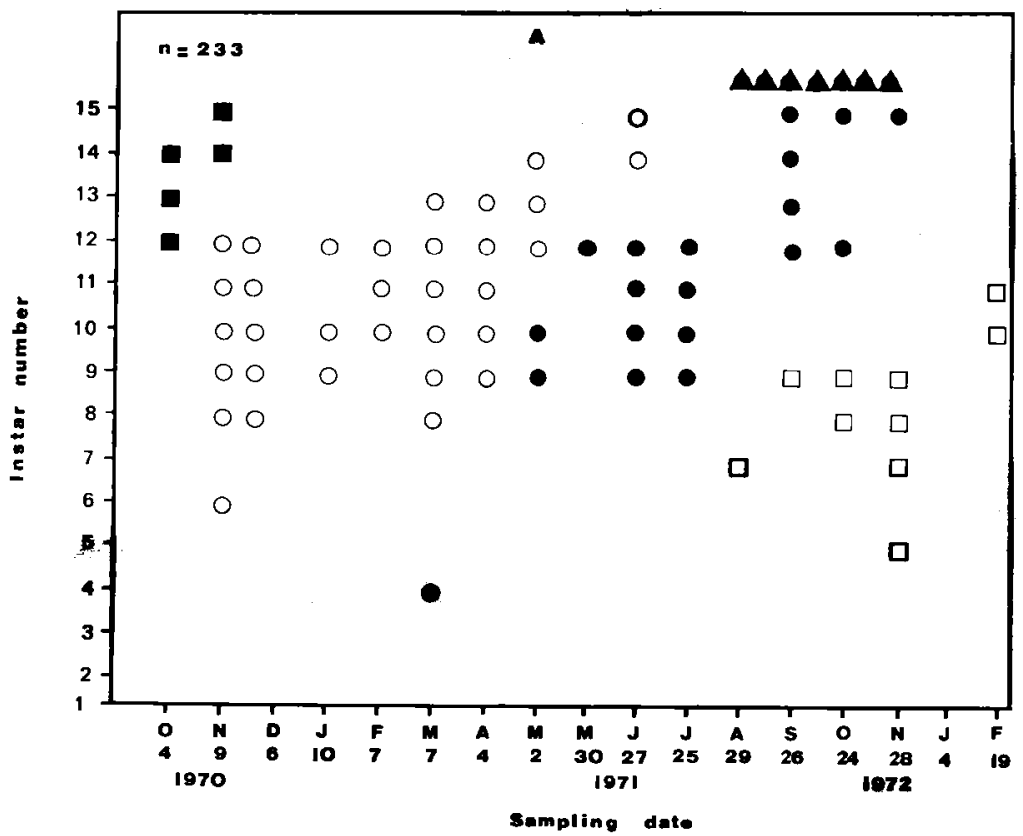

Fig. 3. Size distribution of Megaleptoperla diminuta in Waikoropupu Springs from October 1970 to February 1972. Data from samples at all sites combined. A black triangle indicates that newly shed exuviae were found and an $A$ that adults were collected. Each possible cohort is indicated by a different symbol: closed square, open circle, closed circle or open square.

a life history strategy for populating the seasonal habitat of aquatic plants, but further investigation is required.

Many species of New Zealand and Australian Plecoptera have been shown to have non-seasonal life cycles (sensu Huynes 1970). The presence of poorly synchronised life cycles does not mean that discrete cohorts can not occur (in the case of $M$. diminuta in Waikoropupu Springs, there may be two cohorts present). The emergence period of $M$. diminuta in the Springs extends over several months as occurs with Acroperla trivacuata, $Z$. decorata and Spaniocerca zelandica (Winterbourn 1966, 1978) in New Zealand, and many Australian species (Hynes \&
Hynes 1975). Extended emergence periods and flexible life cycles have been seen as an adaptation to the uncertain Australian climate (Hynes \& Hynes 1975 ) or conversely a response to the mild climate of New Zealand (Devonport \& Winterbourn 1976) as discussed by Towns (1981). It is interesting that this pattern, with ovoviviparity as well, is found in $M$. diminuta in a stable cold spring in New Zealand where Rakiura vernale (Trichoptera : Helicopsychidae) shows a rigid 1 -year life cycle with a very restricted period of emergence (Michaelis 1973).

The non-seasonality of these life cycles has important implications. Assume species A in Australia or New Zealand and an equivalent species $B$ in the Nor- 
Table I. Ovoviviparity (OV) and viviparity (V) reported for Southern Hemisphere Plecoptera and Trichoptera.

\begin{tabular}{|c|c|c|}
\hline $\begin{array}{l}\text { V Triplectides cephalotes } \\
\text { (Trichoptera : Leptocenidae) (N.Z.) }\end{array}$ & Water weeds in ponds and lakes & Pendergrast \& Cowley (1966) \\
\hline $\begin{array}{l}\text { OV Antarctoperla michaelseni } \\
\text { (Plecoptera : Gripopterygidae) } \\
\text { (S. Am.) }\end{array}$ & - & Zwick (1973) \\
\hline $\begin{array}{l}\text { OV Austrocerca tasmanica } \\
\text { (Plecoptera : Notonemouridae) } \\
\text { (Aus.) }\end{array}$ & $\begin{array}{l}\text { Streams, rivers, lake shores } \\
\text { Ponds, pools, grassy streams and } \\
\text { ditches }\end{array}$ & $\begin{array}{l}\text { Hynes (1974) } \\
\text { Hynes (in press) }\end{array}$ \\
\hline $\begin{array}{l}\text { OV Megaleptoperla dimintuta } \\
\text { (Plecoptera : Gripopterygidae) }\end{array}$ & $\begin{array}{l}\text { Vegetation in running water } \\
\text { Higher plants in spring-fed creeks } \\
\& \text { bogs }\end{array}$ & $\begin{array}{l}\text { McLellan (1975) } \\
\text { McLellan (pers. comm.) }\end{array}$ \\
\hline $\begin{array}{l}\text { OV Leptoperla sp. } \\
\text { (Plecoptera : Gripopterygidae) } \\
\text { (Tas., Aus.) }\end{array}$ & - & Zwick $(1980,1981)$ \\
\hline $\begin{array}{l}\text { V Triplectides (5 spp.) } \\
\text { (Trichoptera : Leptoceridae) (Aus.) }\end{array}$ & Temporary waterways & Morse \& Neboiss (1982) \\
\hline
\end{tabular}

thern Hemisphere have the same total population size (i.e. egg, nymph and adult stages), and the adults live for the same number of days. If species $A$ has an extended emergence period, the size of its adult population at any given time is considerably reduced compared to species $B$ with a restricted emergence period. The reduced adult population size of species $\mathrm{A}$ might require additional adaptive mechanisms to ensure reproductive success in locating a mate. These adaptive mechanisms have not been fully explored in the Southern Hemisphere Plecoptera, but drumming with the abdominal tip probably does not occur among the Antarctoperlaria (Zwick 1981). Clearly, further life history studies of Southern Hemisphere Plecoptera are needed.

\section{Acknowledgement:}

This work was financed by the Cawthron Institute and forms part of a PhD thesis carried out in the Zoology Department, University of Canterbury under the supervision of Drs Vida M. Stout and M.J. Winterbourn. I thank Professor H.B.N. Hynes who drew my attention to the importance of the finding of ovoviviparity ; Mr. I.D. McLe\}lan who identified the nymptis and encouraged the work; Dr. R.W.G. White who made Professor Hynes' manuscript on the Tasmanian Plecoptera available to me and Dr. M.J. Winterbourn who helped in the preparation of this manuscript.

\section{Literature ctted}

Cowley (D.R.). 1978. - Studies on the larvae of New Zealand Trichoptera. N.Z. J. Zool., $5: 639-750$.

Crosby (T.K.). 1973. - Dyar's Rule predated by Brooks's Rule. N.Z. Entomol. 5 : 175-176.

Devonport (B.F.) \& Winterboum (M.J.J, 1976. - The feeding relationships of two invertebrate predators in a New Zealand river. Freshwater Biol., 6: 167-176.

Fink (T.J.). 1980. - A comparison of mayfly (Ephemeroptera) instar determination methods in Flannagan J.F. and Marshall K.E. (ed.), Advances in Ephemeroptera Biology. Intemational Conference on Ephemeroptera, 3rd, Winnipeg, Man. 1979:367.380.

Fruehlich (C.G.). 1969. - Studies on Brazilian Plecoptera. 1. Some Gripopterygidae from the biological station at Paranapiacaba. State of Sào Paulo. Beitr. neotrop. Fauna, 6: 17.39.

Helson (G.A.H.). 1935. - Hatching and early instars of Stenoperla prasina. Trans. R. Soc. N.Z., $65: 11-15$.

Hynes (H.B.N.). 1970. - The Ecology of Running Waters. Liverpool University Press, Liverpool. 555 p.

Hynes (H.B.N.). 1974. - Observations on the adults and eggs of Australian Plecoptera. Aust. J. Zool. Suppl. Ser., 29 : 37-52.

Hynes (H.B.N.). 1976. - Biology of Plecoptera. Annu. Rev. Ento mol., 21 : $135-154$.

Hynes (H.B.N.). In press. - Tasmanian Plecoptera. Fauna of Tasmania Handbook No. 7. Fauna of Tasmania Committee, Hobart.

Hynes (H.B.N.) \& Hynes (M.E.). 1975. - The life histories of many of the stoneflies (Plecoptera) of south-eastem mainland Australia. Aust. J. Mar. \& Freshw. Res., 26: 113-153.

Kimmins (D.E.). 1938. - Notes on the Plecoptera of New Zealand. Ann. Mag. Nat. Hisr., $11: 561-580$.

McLellan (I.D.). 1975. - The Freshwater Insects. Ch. XIV in Kuschel, G. (ed.). Biogeography and Ecology in New Zealand. Junk. The Hague : $537-559$.

McLellan (I.D.). 1977. - New alpine and southem Plecoptera from New Zealand, and a new classification of the Gripopterygidae. N.Z. J. Zool., 4 : 119-147. 
Michaelis (F.B.). 1973. - The distribution and life history of Rakiura vernale (Trichoptera : Helicopsychidae). J. R. Soc. N.Z. 3: 295-304.

Michaelis (F.B.). 1976 a. - Watercress (Nasturtium microphyllum (Boenn.) Rchb and $N$. officinale) in New Zealand cold springs. Aquat. Bot., $2: 317-325$

Michaelis (F.B.). 1976 b. - Physico-chemical features of Pupu Springs. N.Z. J. Mar. \& Freshw. Res., $10: 613-628$.

Michaelis (F.B.). 1977. - Biological features of Pupu Springs. N.Z J. Mar. \& Freshw. Res., $11: 357.373$.

Morse (J.C.) \& Neboiss (A.). 1982. - Triplecides of Australia (Insecta : Trichoptera : Leptoceridae) Mem. Nat. Mus Vic. $43: 61-98$.

Pendergrast (J.G.) \& Cowley (D.R.). 1966. - An Introduction to New Zealand Freshwater Insects. Collins, Auckland. 100 p.

Rait (W.L.). 1937. - A study of the growth of the fore wingsheaths in Eusthenia spectabilis (Westwood). Trans. \& Proc. R. Soc. S. Aust., $61: 63-73$.

Sephton (D.H.) \& Hynes (H.B.N.) 1982 a. - The numbers of nymphal instars of several Australian Plecoptera. Aquat. Insects, $4: 153-166$
Sephton (D.H.) \& Hynes (H.B.N.). 1982 b. - Observations on the first instar nymphs of several Australian stoneflies (Plecoptera). Aquat. Insects, $4: 237-252$.

Towns (D.R.). 1981. - Life histories of benthic invertebrates in a kauri forest stream in northern New Zealand. Aust. J. Mar. \& Freshw. Res. $32: 191.211$.

Winterboum (M.J.). 1966 - Studies on New Zealand Stoneflies 2. The ecology and life history of Zelandoperia maculati (Hare). and Aucklandobius trivacuatis (Tillyard)-Gripoplerygidae) N.Z. J. Sci, $9: 312-323$.

Winterboum (M.J.). 1974 - The life histories, trophic relations and production of Stenoperta prasina (Plecoptera) and Deleatidium sp. (Ephemeroptera) in a New Zealand river. Freshwa ver Biol., 4 : $507-524$.

Winterbourn (M.J.). 1978. - The macroinvertebrate faura of a New Zealand forest stream. N.Z. J. Zool., $5: 157.169$.

Zwick (P.). 1973. - Insecta : Plecoptera-Phylogenetisches System und Kalalog. Das Tierreich, 94 : i-xxxii ; 1-465.

Zwick (P.). 1980. - Plecoptera (Steinfliegen). Handbuch der Zoologie Vol. IV. 2 Haltue : Insecia 2. Teil Spezielles Lfg. 26, $7: 115$ p.

Zwick (P.). 1981. - 41. Plecoptera in Keast A. (ed.), Ecological Biogeography of Australia. Junk, The Hague : 1171-1182. 